\title{
COVID-19 pneumonitis and lupus pneumonitis: a challenge in diagnosis and early therapeutic consideration
}

\author{
Ketut Suryana* \\ Department of Internal Medicine, Merpati Clinic, Wangaya HIV Study Group, Allergy and Clinical Immunology
} Services Unit at Wangaya Hospital, Medical Faculty, Udayana University in Denpasar, Bali, Indonesia

Received: 19 December 2021

Accepted: 12 January 2022

*Correspondence:

Dr. Ketut Suryana,

E-mail: ketutsuryana@gmail.com

Copyright: () the author(s), publisher and licensee Medip Academy. This is an open-access article distributed under the terms of the Creative Commons Attribution Non-Commercial License, which permits unrestricted non-commercial use, distribution, and reproduction in any medium, provided the original work is properly cited.

\begin{abstract}
Coronavirus disease 2019 (COVID-19) is an acute respiratory illness caused by severe acute respiratory syndrome coronavirus 2 (SARS-CoV-2) infection. It has various clinical manifestations, from asymptomatic to severe disease with possible multi-organ involvement, with respiratory and vascular systems being the frequent affected. COVID-19 can affect patients with autoimmune diseases including systemic lupus erythematosus (SLE). The concurrent of both diseases may show the similar characteristic which can as a challenge in diagnosis and early therapeutic consideration. We report a case of 53 year-old Balinese woman patient who previously diagnosed with acute respiratory illness (Pneumonitis), The patient with past history of SLE since 2005, takes 200 mg hydroxychloroquine (HCQ) and $4 \mathrm{mg}$ methylprednisolone once a day orally without adverse effect. Then she was confirmed with SARSCoV-2 infection (COVID-19 pneumonitis) concurrent with SLE flare (Lupus pneumonitis). The clinical similarities were fever, dry cough and shortness of breath with the chest X-ray (CXR) was bilateral interstitiil infiltrate. Laboratory results; a positive SARS-CoV-2 polymerase chain reaction test, leucophenia, increased ESR, slightly increased CRP, decreased CD4 and CD8 cell count. Decreased oxygen saturation, requiring 4 L of oxygen via nasal cannula on admission. She was given therapy of antibiotics, antivirus and other symptomatic. The prior SLE maintenance therapy was continued with increasing methylprednisolone dose. The patient's condition was improved and weaned off her oxygen requirements. She was discharged and followed by home isolation for 14 days.
\end{abstract}

Keywords: SARS-CoV-2, COVID-19, SLE flare, Hydroxychloroquine, Methylprednisolone

\section{INTRODUCTION}

COVID-19 is an acute respiratory illness caused by SARS-CoV-2 infection and has become a global concern. SLE is a chronic multisystemic autoimmune disease that leads alterations in various steps of the immune system (decreased of $\mathrm{CD}^{+}$cell count, $\mathrm{CD}^{+}$cell mediated cytotoxicity) and increases of infection tendency. ${ }^{1}$

SARS-CoV-2 is a single stranded enveloped RNA virus which can bind to angiotensin converting enzyme 2 (ACE-2) receptor to enter host cells. ${ }^{2}$ SLE etiology remains unknown, viral infection (COVID-19) has been found to influence the pathogenesis in susceptible individuals, it can cause exacerbations of diseases., ${ }^{3,4}$ When SLE patients present fevers, we should perform a detail clinical investigation, C-reactive protein (CRP) and disease activity markers to distinct between infection and lupus flare that is needed as an early therapeutic consideration. ${ }^{5,6}$ Here, our case; SARS-CoV-2 Infection in an adult female patient with a SLE flare.

\section{CASE REPORT}

A 53-year-old female patient who was admitted due to a COVID-19. She was diagnosed with SLE since 2005, with therapy $4 \mathrm{mg}$ methylprednisolone and $200 \mathrm{mg}$ HCQ once a day orally. 


\section{Progress note}

On May $18^{\text {th }}, 2021$, she came to emergency department with fever, dry cough, sore throat, loss of smell (anosmia) and shortness of breath since 3 days prior to admission. She had been protected by wearing a surgical mask but had contact a week ago with her daughter who had just recovered from COVID-19. Her body temperature of $38.8^{\circ} \mathrm{C}$, blood pressure $120 / 70 \mathrm{mmHg}$, pulse rate 108 times/minute and respiratory rate 28 breaths/minute. CXR showed bilateral interstitial infiltrate (Figure 1).

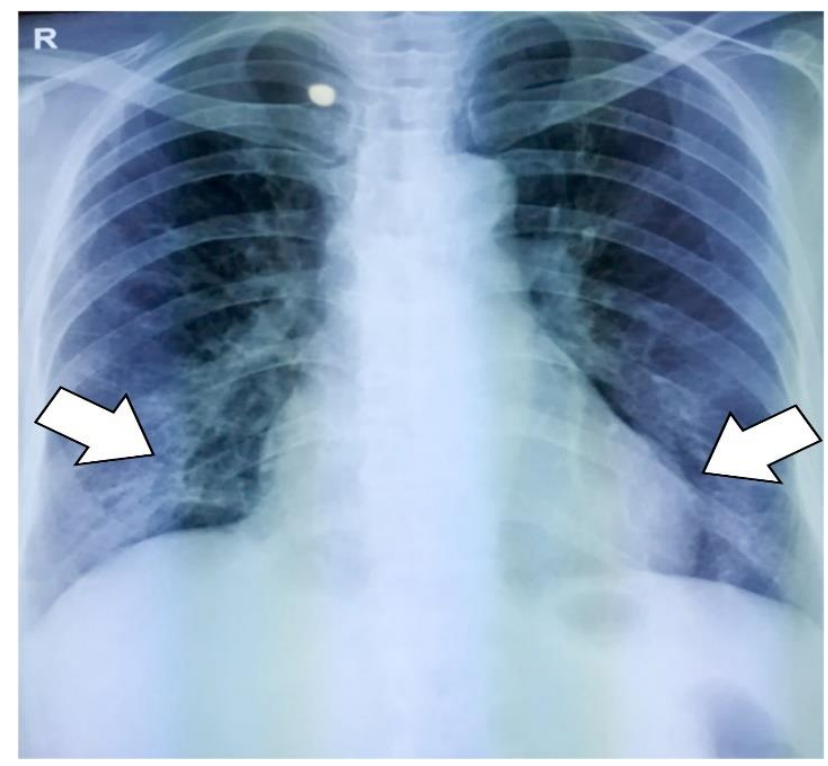

Figure 1: The chest X-ray showed bilateral interstitial infiltrates.

Laboratory results; a decreased WBC (3.84x $\left.10^{3} / \mathrm{ul}\right)$, increased erythrocyte sediment rate (ESR) $32 \mathrm{~mm} /$ hour, oxygen saturation $\left.\left(\mathrm{SpO}_{2}\right) 94 \%\right)$. She was probably of SARS-CoV-2 infection (WHO, 2020) and SLE flare. Empiric therapy, $125 \mathrm{mg}$ methylprednisolone a day intravenously for 3 days, $200 \mathrm{mg}$ HCQ twice a day orally for 5 days, $750 \mathrm{mg}$ levofloxacin a day intravenously for 7 days, $500 \mathrm{mg}$ azithromycin once a day orally for 5 days, and symptomatic therapy.

On the second day of admission, laboratory results; $\mathrm{SpO}_{2}$ (95\%), CRP (12 mg/l) and real-time polymerase chain reaction (RT-PCR) analysis on nasopharyngeal swabs was positive (Table 1). Biomarker changes; WBC count was decreased $3.84 \times 10^{3} / \mu 1$, ESR was elevated $32 \mathrm{~mm} /$ hour, CRP was elevated (Table 2).

She was confirmed with COVID-19 pneumonitis and SLE flare. Therapy was added with antiviral $(75 \mathrm{mg}$ oseltamivir twice a day orally), $600 \mathrm{mg}$ ascorbic acid twice a day intravenously (Figure 2).

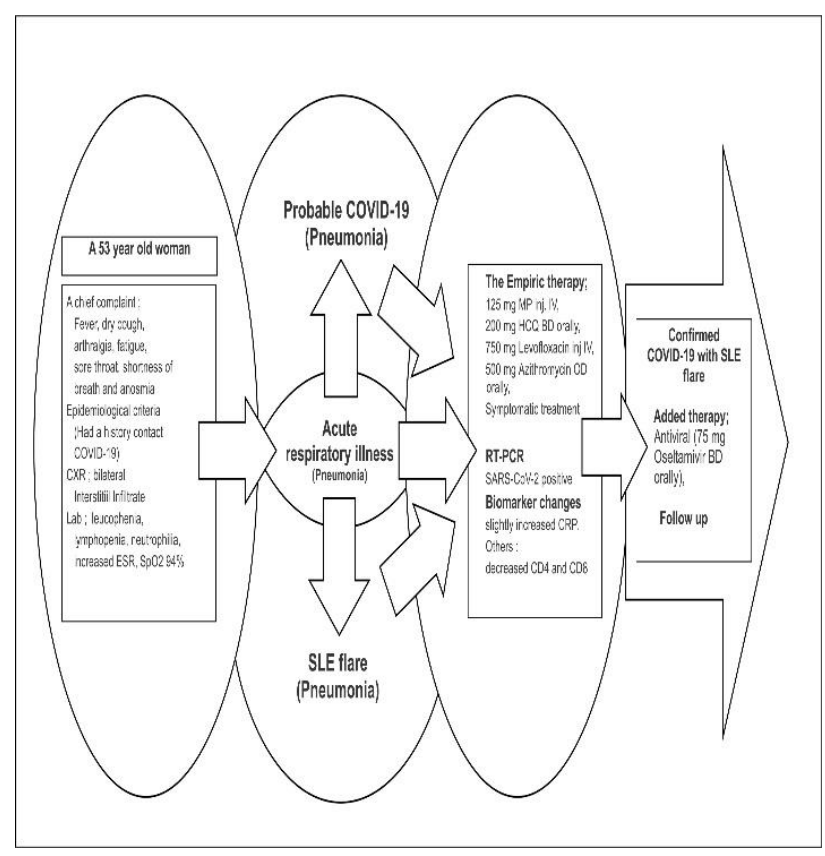

Figure 2. Progress note.

On the fourth day of admission, she was progressed, stable hemodynamic, $\mathrm{SpO}_{2}$ 95\%, methylprednisolone switch to $8 \mathrm{mg}$ twice a day orally. On the seventh day of admission, stable hemodynamic, CXR was normal, $\mathrm{SpO}_{2}$ $97 \%, 8 \mathrm{mg}$ methylprednisolone twice a day orally.

On the tenth day of admission, she had been better, stable hemodynamic, $\mathrm{SpO}_{2} 98 \%$, and RT-PCR SARS-CoV-2 was negative. On the twelfth day, all of the symptoms were relieved, $\mathrm{SpO}_{2} 98 \%$, re-examination of RT-PCR was negative. Levofloxacin $750 \mathrm{mg}$ was stopped on May $25^{\text {th }}$, azithromycin $500 \mathrm{mg}$ on May $23^{\text {th }}$ and antiviral drug on May $24^{\text {th }}$. She was recovered and discharged, followed by home isolation for 14 days and SLE maintenance therapy (Table 3).

Table 1: Clinical laboratory data.

\begin{tabular}{|c|c|c|c|c|c|c|c|}
\hline \multirow[b]{2}{*}{ Laboratory data } & \multirow[b]{2}{*}{$\begin{array}{l}\text { Reference } \\
\text { ranges }\end{array}$} & \multicolumn{3}{|l|}{ Baseline } & \multicolumn{3}{|c|}{ Re-examination } \\
\hline & & $\begin{array}{l}\text { May } 18^{\text {th }} \\
\text { (First } \\
\text { day) }\end{array}$ & $\begin{array}{l}\text { May 19 }{ }^{\text {th }} \\
\text { (Second } \\
\text { day) }\end{array}$ & $\begin{array}{l}\text { May 21 th } \\
\text { (Fourth } \\
\text { day) }\end{array}$ & $\begin{array}{l}\text { May 24 } \\
\text { (Seventh } \\
\text { day) }\end{array}$ & $\begin{array}{l}\text { May 27th } \\
\text { (Tenth } \\
\text { day) }\end{array}$ & $\begin{array}{l}\text { May 29th } \\
\text { (Twelfth } \\
\text { day) }\end{array}$ \\
\hline WBC (×10³/ul) & $4.00-11.00$ & 3.84 & - & - & - & 5.82 & Discharge \\
\hline NEUT $\left(\times 10^{3} / \mathbf{u l}\right)$ & $2.00-7.00$ & 8.94 & - & - & - & 6.88 & - \\
\hline LYM (×103/ul) & $0.80-4.00$ & 0.72 & - & - & - & 2.8 & - \\
\hline NLR & $<3.13$ & 12.4 & - & - & - & 2.4 & - \\
\hline PLT & $150-450$ & 154.000 & - & - & - & 182.000 & - \\
\hline
\end{tabular}




\begin{tabular}{|c|c|c|c|c|c|c|c|}
\hline \multirow[b]{2}{*}{ Laboratory data } & \multirow[b]{2}{*}{$\begin{array}{l}\text { Reference } \\
\text { ranges }\end{array}$} & \multicolumn{3}{|l|}{ Baseline } & \multicolumn{3}{|c|}{ Re-examination } \\
\hline & & $\begin{array}{l}\text { May 18 } \\
\text { (First } \\
\text { day) }\end{array}$ & $\begin{array}{l}\text { May 19th } \\
\text { (Second } \\
\text { day) }\end{array}$ & $\begin{array}{l}\text { May 21 }{ }^{\text {th }} \\
\text { (Fourth } \\
\text { day) }\end{array}$ & $\begin{array}{l}\text { May } 24^{\text {th }} \\
\text { (Seventh } \\
\text { day) }\end{array}$ & $\begin{array}{l}\text { May } 27^{\text {th }} \\
\text { (Tenth } \\
\text { day) }\end{array}$ & $\begin{array}{l}\text { May } 29^{\text {th }} \\
\text { (Twelfth } \\
\text { day) }\end{array}$ \\
\hline Hemoglobin (g/dl) & $11.0-15.0$ & 13.7 & - & - & - & 13.4 & - \\
\hline ESR (mm/hour) & $0-20$ & 32 & - & - & - & - & - \\
\hline CD4 (cells/ $\mu \mathrm{L})$ & $404-1612$ & - & 384 & - & - & - & - \\
\hline CD8 $($ cells $/ \mu \mathrm{L})$ & $220-1129$ & - & 204 & - & - & - & - \\
\hline Urine protein & Negative & Negative & - & - & - & Negative & - \\
\hline $\mathrm{SpO}_{2}(\%)$ & $93-98$ & 94 & 95 & 95 & 97 & 98 & 98 \\
\hline $\mathrm{Na}+(\mathrm{mmol} / \mathrm{L})$ & $136-146$ & 142 & - & - & - & - & - \\
\hline $\mathrm{K}+(\mathbf{m m o l} / \mathrm{L})$ & $3.4-4.5$ & 3.6 & - & - & - & - & - \\
\hline $\mathrm{Cl}(\mathrm{mmol} / \mathrm{L})$ & $98-106$ & 102 & - & - & - & - & - \\
\hline ALT (U/L) & $7-40$ & 124 & - & - & - & 62 & - \\
\hline AST (U/L) & $13-35$ & 108 & - & - & - & 46 & - \\
\hline $\begin{array}{l}\text { Albumin } \\
\text { (gm/dL) }\end{array}$ & $3.8-5.1$ & 3.9 & - & - & - & - & - \\
\hline $\begin{array}{l}\text { Creatinine } \\
(\mathrm{mg} / \mathrm{dL})\end{array}$ & $0.5-1.2$ & 2.4 & - & - & - & 1.2 & - \\
\hline $\begin{array}{l}\text { Urea nitrogen } \\
\text { (mg/dL) }\end{array}$ & $6-21$ & 44 & - & - & - & 28 & - \\
\hline D-dimer (mg/L) & $<1000$ & - & 304 & - & - & - & - \\
\hline CRP (mg/L) & $<10$ & - & 12 & - & - & - & - \\
\hline RT-PCR & Negative & & Positive & & & Negative & Negative \\
\hline
\end{tabular}

Table 2: Comparison of biomarker changes between COVID-19 pneumonitis and lupus pneumonitis (SLE flare).

\begin{tabular}{|c|c|c|}
\hline Biomarker & COVID-19 pneumonitis, (Infection) & Lupus pneumonitis, (SLE flare) \\
\hline WBC & Elevated & Reduced \\
\hline ESR & Elevated & Elevated \\
\hline CRP & Elevated & No change or minimally elevated \\
\hline
\end{tabular}

Table 3: Timeline of disease course according to days from initial until discharge.

\begin{tabular}{|c|c|c|c|c|c|c|c|c|c|c|c|c|c|}
\hline \multirow{2}{*}{ Variables } & \multirow[t]{2}{*}{ Home } & \multicolumn{11}{|c|}{ Hospital } & \multirow{2}{*}{$\begin{array}{l}\text { Discharge } \\
\text { D12 }\end{array}$} \\
\hline & & D1 & D2 & D3 & D4 & D5 & D6 & D7 & D8 & D9 & D10 & D11 & \\
\hline Day of illness & $15-17$ & 18 & 19 & 20 & 21 & 22 & 23 & 24 & 25 & 26 & 27 & 28 & 29 \\
\hline Fever & & 38.8 & 37.9 & & & & & & & & & & \\
\hline \multicolumn{14}{|l|}{ Dry cough } \\
\hline \multicolumn{14}{|l|}{$\begin{array}{l}\text { Shortness of } \\
\text { breath }\end{array}$} \\
\hline \multicolumn{14}{|l|}{ Sore throat } \\
\hline \multicolumn{14}{|l|}{ Anosmia } \\
\hline Chest X-ray & & + & & & & & & - & & & & & \\
\hline RT-PCR & & & + & & & & & & & & - & & - \\
\hline Glucocorticoids & \multicolumn{13}{|c|}{ Glucorticoids } \\
\hline $\begin{array}{l}\text { Hydroxy- } \\
\text { chloroquine }\end{array}$ & \multicolumn{13}{|c|}{ Hydroxychloroquine } \\
\hline \multirow{2}{*}{ Antibiotic } & \multicolumn{13}{|c|}{ Levofloxacin $750 \mathrm{mg}$} \\
\hline & \multicolumn{13}{|c|}{ Azythromicin $500 \mathrm{mg}$} \\
\hline Anti-viral & \multicolumn{13}{|c|}{ Oseltamivir $75 \mathrm{mg}$} \\
\hline $\begin{array}{l}\text { Oxygen } \\
\text { saturation (\%) }\end{array}$ & & 94 & 95 & & 95 & & & 97 & & & 98 & & 98 \\
\hline
\end{tabular}

Chest X-Ray (+), infiltrate, Chest X-Ray (-), No-infiltrate, RT-PCR, Real-Time polymerase. 


\section{DISCUSSION}

SARS-CoV-2 infection clinical manifestations include fever, dry cough, fatigue, myalgia, sore throat, shortness of breath, anorexia/nausea/vomiting, diarrhea, anosmia or ageusia (loss of taste), can alter mental status. The epidemiological criteria: working or traveling to an area with high risk of viral transmission, within 14 days prior to symptom onset. Probable of COVID-19 is a person who meets clinical criteria above and contacts to a probable or confirmed case, or links to a COVID-19 cluster, with CXR findings suggested of COVID-19. Confirmed SARS-CoV-2 infection is a person with a positive nucleic acid amplification test (NAAT). ${ }^{7}$

On first day admission, she complaint of fever, dry cough, sore throat, anosmia and shortness of breath since 3 days prior to admission and she had contact a week ago with her daughter who had just recovered from COVID19. The CXR findings suggested of COVID-19 disease. On the second day of admission, the nucleic acid amplification test (NAAT) was positive. She was confirmed with SARS-CoV-2 infection.

Diagnosis of SLE flare is primarily made on clinical grounds after exclusion of other diseases, mostly infections. Symptom of fever is a typical not only of infection but also SLE flare. The difference of fever causes, infection or lupus flare, requires directly opposite therapy from each other. Fever infection related needs antibiotics, fever lupus flare up related needs immunosuppressive therapy including corticosteroids. ${ }^{8,9}$ Comparison of biomarker changes between infection and SLE flare; WBC is elevated in SLE with infection, but in SLE flare leukocyte count remains unchanged or reduced. ESR is elevated in both SLE with infection and SLE flare. CRP is elevated in SLE with infection and minimally elevated or no change in SLE flare. ${ }^{10,12}$

She complaint of fever, dry cough, sore throat, anosmia and shortness of breath for 3 days prior to admission. Biomarker changes; WBC count was decreased $3.84 \times 10^{3} / \mu 1$ (generally occurred in SLE flare). ESR was elevated $32 \mathrm{~mm} /$ hour (may occur both in SLE with infection and SLE flare up). CRP was elevated, it may occur both in SLE with infection and in SLE flare. CXR showed bilateral interstitial infiltrates. She was confirmed with SARS-CoV-2 infection (COVID-19 pneumonitis) and SLE flare (Lupus pneumonitis).

SLE patients are more susceptible to SARS-CoV-2 infection than general population, so it is essential to continue the lupus therapy during the COVID-19 pandemic to ensure the stable remission lupus. Currently, it would seem wise to consider continue corticosteroids to decrease the risk of SLE flare. No evidence that the use of HCQ worsens the course of disease. Continuing HCQ to help in preventing disease flare would seem wise. The "new paradigm" in SLE therapy recommendation are Corticosteroids; 125-500 mg methylprednisolone/pulse for 3 days and tapering to minimal for maintenance dose. In COVID-19 with SLE flare combines Corticosteroids with $200 \mathrm{mg}$ HCQ twice a day orally for 5 days and continues with $200 \mathrm{mg}$ HCQ only once a day orally. ${ }^{13,15}$ In this patient, the regimen was $125 \mathrm{mg}$ methylprednisolone injection intravenously (for 3 days) and reduced each a week (tapering) to the maintenance dose. It combined with $200 \mathrm{mg}$ HCQ twice a day orally (for 5 days) and continued with $200 \mathrm{mg}$ HCQ once a day orally. Antiviral (75 mg oseltamivir twice a day orally) for 5 days, antibiotic for 7 days and other supportive therapy. She was recovered and discharged, continued by home isolation for 14 days with SLE maintenance therapy (4 mg methylprednisolone twice a day and 200 mg HCQ once a day orally).

\section{CONCLUSION}

SLE flare can be triggered by SARS-CoV-2 infection. The long-term SLE therapy with a low dose corticosteroid and HCQ has made the patient to be remission and stable. But in the other hand the diagnosis and early therapeutic consideration for SARS-CoV-2 infection (COVID-19) in SLE patient is still a challenge up to now. There is no guideline therapy for this type of the case. We wish to see the SLE patient with COVID-19 to be observed and monitored strictly to get an optimal outcome.

\section{Funding: No funding sources \\ Conflict of interest: None declared \\ Ethical approval: Not required}

\section{REFERENCES}

1. He F, Luo Q, Lei M, Fan L, Shao X, Hu K et al. Successful recovery of recurrence of positive SARSCoV-2 RNA in COVID-19 patient with systemic lupus erythematosus: a case report and review. Clinical rheumatol. 2020;39(9):2803-10.

2. Spihlman AP, Gadi N, Wu SC, Moulton VR. COVID-19 and Systemic Lupus Erythematosus: Focus on Immune Response and Therapeutics. Front. 2020;30(11):589474.

3. Illescas-Montes R, Corona-Castro CC, MelguizoRodríguez L, Ruiz C, Costela-Ruiz VJ. Infectious processes and systemic lupus erythematosus. Immunology. 2019;158(3):153-60.

4. Caso F, Costa L, Ruscitti P, Navarini L, Del Puente A, Giacomelli R et al. Could Sars-coronavirus-2 trigger autoimmune and/or autoinflammatory mechanisms in genetically predisposed subjects? Autoimmun Rev. 2020;19(5):102524.

5. Di Bartolomeo S, Alunno A, Carubbi F. Respiratory Manifestations in Systemic Lupus Erythematosus. Pharmaceuticals (Basel). 2021;18;14(3):276.

6. Thanou A, Sawalha AH. SARS-CoV-2 and Systemic Lupus Erythematosus. Curr Rheumatol Rep. $2021 ; 28 ; 23(2): 8$ 
7. WHO. WHO COVID-19: Case Definitions, 2019. Available at: https://www.who.int/publications/i/item/WHO-2019nCoV-Surveillance_Case_Definition-2020. Accessed on 16 December 2020.

8. Adamichou C, Bertsias G. Flares in systemic lupus erythematosus: diagnosis, risk factors and preventive strategies. Mediterr J Rheumatol. 2017;28(1):4-12.

9. Gensous N, Marti A, Barnetche T, Blanco P, Lazaro $\mathrm{E}$, Seneschal J et al. Predictive biological markers of systemic lupus erythematosus flares: a systematic literature review. Arthritis Res Ther. 2017;19(1):238.

10. Jung JY, Suh CH. Infection in systemic lupus erythematosus, similarities, and differences with lupus flare. Korean J Intern Med. 2017;32(3):429-38.

11. Kakati S, Teronpi R, Barman B. Frequency, pattern and determinants of flare in systemic lupus erythematosus: A study from North East India. Egyptian Rheumatol. 2017;37.

12. Gracia-Ramos AE, Saavedra-Salinas MÁ. Can the SARS-CoV-2 infection trigger systemic lupus erythematosus? A case-based review. Rheumatol Int. 2021;41(4):799-809.
13. Porta S, Danza A, Arias Saavedra M, Carlomagno A, Goizueta MC, Vivero F, Ruiz-Irastorza G. Glucocorticoids in Systemic Lupus Erythematosus. Ten Questions and Some Issues. J Clin Med Aug. 2020;21;9(9):2709.

14. Basta F, Fasola F, Triantafyllias K, Schwarting A. Systemic Lupus Erythematosus (SLE) Therapy: The Old and the New. Rheumatol Ther. 2020;7(3):43346.

15. Lo CH, Wang YH, Tsai CF, Chan KC, Li LC, Lo TH et al. Association of hydroxychloroquine and cardiac arrhythmia in patients with systemic lupus erythematosus: A population-based case control study. PLoS One. 2021;16(5):e0251918.

Cite this article as: Suryana K. COVID-19 pneumonitis and lupus pneumonitis: a challenge in diagnosis and early therapeutic consideration. Int $\mathbf{J}$ Adv Med 2022;9:161-5. 